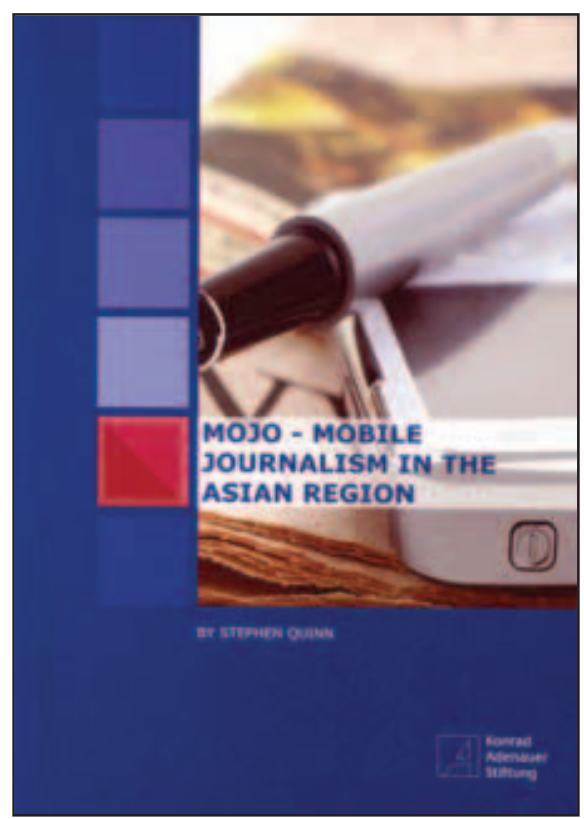

Mojos tend to work alone, in comparison to video journalists for instance who tend to operate in a small team. Mobile technology allows the mojo journalist to operate thus in a more discreet and faster way. The book is organised around five small chapters, outlining what mobile journalism is, how to be a mobile journalist, techniques of mojo reporting and how to address workflows issues. There is undoubtedly a need for new newsroom structures that are relevant for knowledge-age workforces and Quinn provides here suggestions that best support mojo journalism. Ethical and privacy issues are very briefly touched. As the author says, codes of ethics vary enormously in the Asian region which makes it very difficult to provide overall guidelines.-Dr Evangelia Papoutsaki is associate professor in communication studies at Unitec, Auckland.

\section{Vital media resource}

\section{Routledge Companion to News and Journalism, edited by Stuart Allan.} London: Routledge, 2010. 642 pp. ISBN 9780-415-46529-8

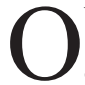
VER the past two decades, all aspects of media-communication have been reshaped by economic, technological and social forces. It is difficult to track these multiple changes and to evaluate their general significance. All sub-fields of media-communication research contain burgeoning literatures in need of conceptual and empirical classification. Major publishers are rapidly addressing this situation.

Wiley-Blackwell, for example, have recently produced handbooks in the fields of Global Communication, Global Communication and Media Ethics, Internet Studies, Intercultural Communication, Media Audiences and the Political Economy of Communication. The Routledge Companion of News and Journalism is a welcome addition to this genre. Editor Stuart Allan has done remarkably well to arrange 56 chapters and 


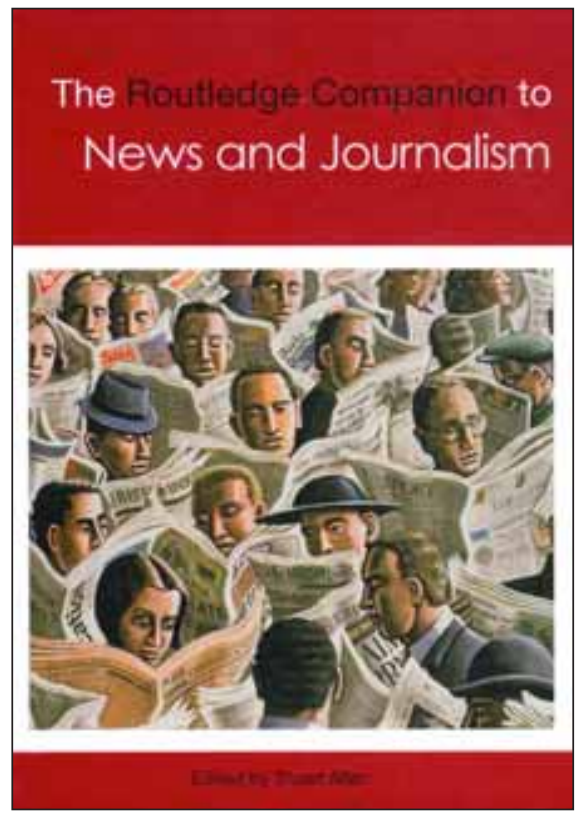

an introductory essay across 636 pages of text. One is immediately struck by the size and complexity of this field. The Companion's articles consider the ideals and professional histories of journalism, sub-categories of journalistic practice (photo, sports, investigative and autobiographical journalism) along with the national, cultural and gender specificities of practising journalists. Other articles place journalism and news media content within broader contexts. Thus, various authors discuss radio-news publics, development journalism, international news flows, nationallyspecific news media organisations and the global ecology of television network news. One particular section of the book deals with the interlinked processes of news gathering, news construction and news presentation across different media platforms.Another section is devoted to normative evaluations of news and journalism. Such articles deal with infotainment, tabloidisation, public sphere principles and racial diversity in news reporting and news stories.

A number of articles deal with the social reception of news media content. Important themes here include citizenship and public knowledge, ethnographies of news consumption, news consumption and social memory. Another set of chapters looks at news and journalism against the backdrop of crisis and conflict. Relevant titles here include 'Journalists and war crimes', 'Peace journalism', 'News and foreign policy', 'Reporting the climate change crisis', 'Iconic Photojournalism and Absent Images:Democratisation and Memories of Terror'. The historic significance of digitalisation and internet communication is considered in Mark Deuze's 'Journalism and convergence culture' and Natalie Fenton's 'News in the Digital Age'. The economic plight of newspapers and newspaper workers in Western countries is sharply depicted in James Compton's 'Newspapers, labour and the flux of economic uncertainty'. The globalisation of media-communication is 
detailed in Simon Cottle's 'Global crises and world news ecology', in Lisbeth Clausen's 'International news flow' and in Dayan Thussu's 'Television news in the era of global infotainment'. The proliferation of non-Western journalism and news media is acknowledged in Qing Cao's 'Journalism and political change: The case of China' and in Silvio Waisbord's 'Rethinking development journalism'. My abiding impressions from this Companion are somewhat contradictory. In one sense the sheer diversity of news organisations and journalistic practices testifies to their resilience. It is equally evident, however, that the critical functions of news and journalism are vulnerable to commercial pressures, state and military coercion and the pervasiveness of global media spectacles.

Furthermore, news organisations and journalists cannot assume the existence of a public domain and an informed citizenry. Our intensely mediated world may be inhabited by atomised, depoliticised people without the capacity for public argument. Whatever one's point of view, this Companion will serve as a vital resource for media academics, journalism educators, media professionals, political participants and all others of an inquiring mind. -Dr Wayne Hope is associate professor communication studies at AUT University.

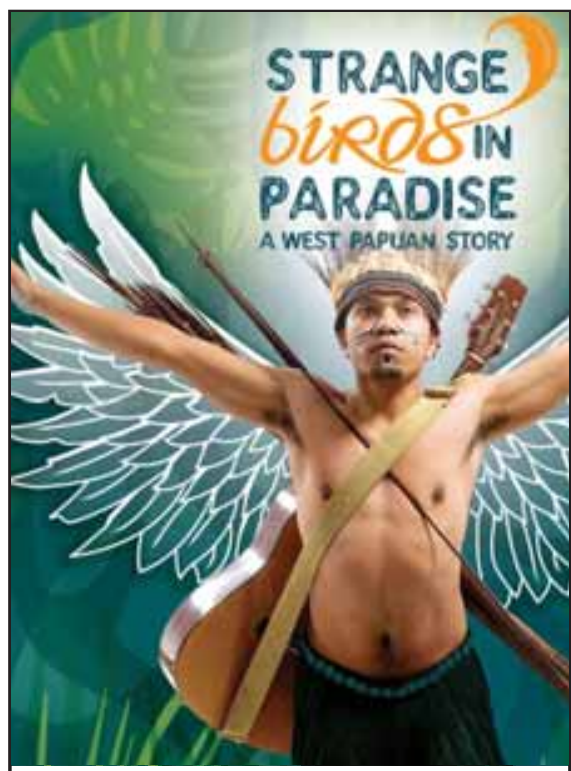

A special screening of the award-winning documentary by Charlie Hill-Smith.

Indonesia Human Rights

Committee (IHRC)

Amnesty International

Auckland (Al)

Pacific Media Centre (PMC)

Place: Academy Cinema (below

Auckland City Library)

Date: Thursday, 20 October 2011

Time: $6 \mathrm{pm}$ - nibbles and drink

\section{$6.45 \mathrm{pm}$ - movie starts}

Tickets: \$20 - Waged \$10 - Unwaged/Students 